Open Access

\title{
The Triple Helix model and the competence set: human spare parts industry under scrutiny
}

\author{
Markku Sotarauta* (D) and Tuomo Heinonen
}

\author{
* Correspondence: \\ markku.sotarauta@uta.fi \\ School of Management, University \\ of Tampere, Kanslerinrinne 1, \\ Fl-33014 Tampere, Finland
}

\begin{abstract}
The main aims of this paper are (a) to construct a generic conceptual model for the Triple Helix model based on competence sets and hence (b) to identify the systemlevel generic competencies needed in the emergence of a new industry. This paper suggests that to gain additional analytical leverage on the Triple Helix model, we need to study it also by focusing on generic competencies called for in the interaction between the main institutional spheres. Hence, there is a need to focus on interacting and conflicting system-level generic competencies that either enhance or hamper innovation processes. It is believed here that a competence set is the core of any Triple Helix constellation, but it is also believed that different competencies are manifested in a variety of ways depending on the nature of the specific system and related industries. The competence set model is elaborated upon by using the emergence of human spare parts industry in Tampere, Finland, as an illustrative case to highlight the otherwise conceptual discussion.
\end{abstract}

Keywords: Innovation system, Competence, University, Regenerative medicine, Human spare parts, Finland

JEL classification: $\mathrm{O} 31, \mathrm{O} 32, \mathrm{O} 33$ 


\section{Résumé}

Les objectifs principaux de cet article sont : (a) de construire un modèle conceptuel générique de Triple Hélice basé sur le jeu des compétences et ainsi (b) d'identifier les compétences génériques au niveau système nécessaires à l'émergence d'une nouvelle entreprise. Cet article suggère que pour obtenir un effet de levier analytique supplémentaire sur le modèle de la Triple Hélice, il importe de l'étudier également en mettant l'accent sur les compétences génériques nécessaires à l'interaction entre les principales sphères institutionnelles. Par conséquent, il est nécessaire de s'appesantir sur les compétences génériques d'interaction et d'antagonisme au niveau système qui favorisent ou handicapent les processus d'innovation. Cet article admet que le jeu de compétences est le cœur de toute constellation de Triple Hélice; il admet également que les différentes compétences se manifestent d'une variété de façons, selon la nature du système considéré et les entreprises associées. Le modèle de jeu de compétences est conçu en utilisant comme illustration l'émergence de l'industrie des pièces de rechange humaines à Tampere, en Finlande, pour mettre en évidence une discussion autre que conceptuelle.

\section{Resumen}

Los principales objetivos de este trabajo son: (a) la construcción de un modelo conceptual genérico para el modelo de la Triple Hélice en base a "conjuntos de competencias," y por tanto (b) identificar las competencias genéricas a nivel de sistema necesarias para el surgimiento de nuevas industrias. Este documento sugiere una mejora al modelo de la Triple Hélice que consiste en elevar la importancia de competencias genéricas dentro del análisis institucional. Por tanto, enfatizamos la necesidad de centrarse en la interacción y el conflicto de competencias transversales a nivel de sistema que pueden exacerbar o dificultar los procesos de innovación. Creemos que un conjunto de competencias es el núcleo de cualquier constelación de la Triple Hélice, pero también creemos que las diferentes competencias se manifiestan en una variedad de formas, dependiendo de la naturaleza de cada sistema de innovación y cada industria. llustramos el modelo propuesto de conjuntos de competencias con un análisis del surgimiento de la industria de prótesis humanas en Tampere, Finlandia.
摘要
本文的主要目的是:(一)基于竞争力集构建三螺旋的一般概念模型;(二)确定在一个 新产业出现过程中所需要的系统级的一般竞争力。本文认为,为了获得分析三螺 旋模型的其他分析工具,我们也需要专注于要求主要机构范畴之间相互作用的一 般竞争力研究。因此,有必要聚焦于相互作用和相互冲突的系统级一般竞争力,不 论它是加强还是防碍创新过程。在此我们相信:一个竞争力集是所有三螺旋星座 的核心;我们也相信:不同的竞争力通过各种不同方式表现出来,取决于具体的系统 和相关产业的性质。通过人类备件产业在芬兰坦佩雷的出现，本文详细说明了竞 争力集模型，以此作为典型案例突出这个相反的一般概念的讨论。 


\begin{abstract}
Аннотация
Основными целями данной статьи являются: (а) создание общей концептуальной модели Тройной спирали, основанной на компетенциях, и, опосредованно, (б) определение соответствующих компетенций, учитывающих специфику условий формирования современной промышленности. В настоящей работе выдвинуто предположение, что для достижения дополнительных преимуществ в рамках модели Тройной спирали, мы должны проанализировать общие компетенции, необходимые для взаимодействия основных институтов друг с другом. Так, существует потребность в общих умениях в области деловых переговоров и решения конфликтов, которые опосредованно могут как улучшить, так и затормозить инновационный процесс. Существует мнение, что набор компетенций составляет основу Тройной спирали, а также что различные компетенции проявляются по-разному в зависимости от условий, в которых складывается такая система, и отраслей, относящихся к ней. Модель набора компетенций разработана с использованием индустрии подготовки кадров в Тампере, Финляндия в качестве примера, способного проиллюстрировать ведущиеся обсуждения.
\end{abstract}

\title{
Resumo
}

O objetivo desse artigo é: (1) de construir um modelo conceitual genérico para o modelo de hélice tríplice baseado em conjunto de competências e, portanto, (b) de identificar as competências genéricas no nível do sistema necessárias na emergência de uma nova indústria. Esse artigo sugere que para ganhar vantagem analítica adicional no modelo de Hélice Tríplice, é necessário estuda-lo também se concentrando nas competências genéricas requeridas para a interação entre as principais esferas institucionais. Consequentemente, existe uma necessidade de focar na interação e nos conflitos no nível das competências genéricas que tanto fortalecem quanto prejudicam o processo de inovação. Acredita-se que um conjunto de competências definido é o coração de qualquer uma constelação da Hélice Tríplice, mas também se acredita que competências diferentes são manifestadas de diversas maneiras dependendo da natureza do sistema específico ou das indústrias relacionadas. O Modelo de definição do conjunto de competências é elaborado com base na emergência da indústria de reposição de peças humanas em Tampere, Finlândia como um caso ilustrativo que põe em evidência a discussão de outra forma conceitual.

\section{Multilingual abstract}

Please see Additional file 1 for translation of the abstract into Arabic.

\section{Introduction}

Universities have increasingly been seen as the core instruments of local, regional and national economic development. This may be a result of the observation that, as many traditional industries have been hollowing out, and as many local economies have been losing their leading firms, the university often emerges as one of the few solid and locally rooted resources to draw upon. It is one of the cores in the dynamic interaction between 'the three institutional spheres', universities, industries and government, fostering entrepreneurship, innovation and economic growth (Etzkowitz and Leydesdorff 1997; Etzkowitz 2008). The core idea of the Triple Helix model revolves around three 
basic premises: (1) universities are playing a central role in innovation side by side with industries and governments; (2) while earlier innovation policy was to a large extent designed and implemented by governments, today, it is fairly commonly an outcome of complex interplay between governments, industries and universities; and contradictorily, the Triple Helix also argues that (3) in addition to taking care of their traditional functions, the three institutional spheres adopt new roles and also perform the roles of the other spheres. In this model, actors taking non-traditional roles are seen especially important and potential sources of innovation (Etzkowitz and Leydesdorff 1997; Etzkowitz 2008).

Drawing upon their literature review, Cai and Cui (2015) maintain that the Triple Helix model has not been free of problems. It is criticised for remaining at an abstract level, lacking solid theoretical basis at a microlevel, not adequately addressing the issues emerging when actors adopt each other's roles and lacking the contextual sensitivity across countries and social settings (Cai and Cui 2015). Additionally, in spite of the fact that the concept of competence is, at least implicitly, strongly linked to the Triple Helix literature, it has only recently gained more attention (Ranga and Etzkowitz 2013). Lester $(2007,1)$ crystallises the increased need to better understand competences related to innovation systems by arguing that there are clear differences in the overall capabilities of nations and regions to adapt to the global economy with equal success. Some simply seem to be better in taking up new technological and market knowledge and to apply it effectively. In Triple Helix constellations, competences (in direct and/or indirect interaction) generate, stimulate and/or frame the overall functioning of a system and its transformation (Eliasson 2000). Consequently, as suggested by Ranga and Etzkowitz, competences also shed light on the ways main actors come together in 'consensus spaces', and move to construct 'innovation spaces' for realisation of the goals articulated in a consensus space (see Ranga and Etzkowitz 2013). Our earlier studies in Finland reveal that while the main actors may trust each other's integrity and trustworthiness, they may have difficulties in trusting mental models and specific profession-based capabilities of 'the others' (Sotarauta et al 2003).

This paper suggests that to gain additional analytical leverage on the Triple Helix model, and the three spaces in the core of it, we need to study it also by focusing on generic competences called for in the interaction between the main institutional spheres. The concept of generic competence refers to those higher order abilities that are called for to learn, innovate, anticipate and create and/or to generate conditions for learning and innovation (cf. Brown 1994; Wadhwa and Rao 2000).

As suggested by the ever expanding Triple Helix literature, there is a need to find a way to link the concept of competence in the debate by reaching beyond the narrow organisational view. For these reasons, this paper constructs a competence set model aim being to contribute to the Triple Helix debate. This paper is built on an assumption that, when enhancing the interaction between the three institutional spheres, there is a need to understand how a set of competences can be shaped for a more productive collaboration. It is exactly to this end, the competence set model is introduced to discuss the interconnected nature of generic competences required in innovation, business growth and economic renewal. The second assumption thus is that by the competence set model, it is possible to understand how competences are spread across the three institutional spheres and several organisations. The competence set is a configuration 
of competences that in direct and indirect interaction generates new knowledge as well as its diffusion and valorization (see Eliasson 2000).

The two interrelated research questions we set out to address are what kind of generic competences are called for in the emergence of a new science-based industry and how do generic competences interact in a Triple Helix constellation. For this end, the focus in this paper is on system-level generic competences instead of the competences of an individual organisation. The concepts of competence and the competence set are elaborated upon by using the emergence of human spare parts industry in Tampere, Finland, as an illustrative case to highlight the otherwise conceptual discussion.

\section{Towards a competence set model in the context of Triple Helix}

\section{The concept of core competence}

In organisation and management studies, the concept of core competence has become one of the key concepts in the efforts to understand why some firms succeed while others do not, and, as it is believed in this paper, it has a potential to add analytical leverage also in studies focusing on Triple Helix constellations. The key rationale in bringing these fairly disconnected bodies of literature together is that there is much to be learnt across these broad fields of knowledge. In competence thinking, the basic idea is that an organisation should comprehend its own core competences and capabilities in order to utilise the resources available (Pralahad and Hamel 1990). It is also assumed that competences change more slowly than products and markets, and hence, the identity of an organisation should not depend on products and markets but on something more lasting, something that lies at the very core of the organisation's activities and success (Tuomi 1999, 82-83). Durand $(1998,306)$ connects competences directly to an organisation's resources and property and to individual and organisational capabilities, knowledge, processes, routines and culture. Javidan $(1998,62)$ uses the concept of competence to refer to the combining and coordinating of capabilities cutting across functions. Core competence, drawing upon the theory of Pralahad and Hamel (1990), may be defined predominantly as a collective learning process across the innovation system. For its part, generic competence is taken here to be specifically capability and expertise that is potentially common to several organisations in a Triple Helix constellation but may also be embedded in a single organisation that has a central position in a system. Generic competences are thus distributed over many operations either within an organisation or across them, and therefore, from the Triple Helix point of view, it is essential to approach them from systemic instead of organisational perspectives. For that purpose, a conceptual link between competence thinking and Triple Helix is constructed by a competence set model.

\section{From competence bloc theory to competence set model}

The competence set model is inspired by the competence bloc theory (Eliasson 2000), but as the competence bloc theory was mainly constructed to better understand and explain business growth in biotechnology, it needs to be extended with additional competences to provide an analytical tool for broader scrutiny of Triple Helix constellations. The competence of actors and their interaction determines the quality of a competence set and, as assumed here, also interaction in the context of a Triple Helix. 
Additionally, a set of competences attracts competent investors who contribute positively to the attractiveness of a Triple Helix constellation (Eliasson 2000). A minimum critical competence mass and variety are needed before a Triple Helix becomes truly functional, and, according to Eliasson and Eliasson (1996), the following actors usually play central roles (modified slightly): (a) competent and active customers and users, (b) innovators who combine new knowledge and technologies in novel ways, (c) entrepreneurs who identify profitable innovations and prepare them for initiation in the market, (d) competent venture financiers who recognise and finance the entrepreneurs, (e) exit markets that facilitate ownership change and (f) industrialists and other established actors who take successful innovations to industrial-scale production. (Eliasson and Eliasson 1996).

Eliasson (2000) strongly associates competences with the selection of winning technologies and corporate winners, and conversely losing technologies and corporations, and thus, it adds analytical leverage to the Triple Helix relationships that are, according to Cai (2014), 'about competition and cooperation for resources, redistribution of power, and network building'. However, importantly, the Triple Helix model reminds that the question is not only about selection of 'winners' and 'losers', or individual companies or narrow industrial sectors, but also more profoundly and broadly about extensive collaboration across institutional spheres for economic growth and renewal. Thus, the question is about how new knowledge emerges, how it generates variation and how selection is made, and thus, moving beyond the narrow organisational and sector-based approaches is fundamental to better support construction of knowledge, consensus and innovation spaces that play a central role in Triple Helix constellations (Ranga and Etzkowitz 2013).

As Ranga and Etzkowitz (2013) maintain, the main ingredient in a knowledge-based economic development is the creation of a knowledge space that, according to them, 'encompasses the competences of knowledge generation, diffusion and use of the Triple Helix components'. They define consensus space to refer to a venue that brings together actors from different organisational backgrounds and perspectives for generating new strategies and ideas, the ultimate goal being novel discoveries and related innovations. For its part, innovation space refers to new organisational mechanisms that are geared towards 'the development of local innovative firms, in parallel with the attraction of talent and innovative firms from elsewhere, the creation and development of intellectual and entrepreneurial potential, and competitive advantage for the region and the country' (Ranga and Etzkowitz 2013, 247).

Applying Eliasson's (2000) conceptualisation, the competence set is defined as a configuration of generic competences that in direct and indirect interaction generates new knowledge as well as its diffusion and valorisation. In other words, competence set is a group of competences, which belong together or are usually found together. Basically, the competence set refers to the ability to achieve new forms of competitive advantage by highlighting the need to continuously renew competences so as to achieve congruence with the changing environment. Moreover, the competence set model may prove useful in the many efforts to boost innovation spaces, i.e. finding new ways to combine capital, technology knowledge and business expertise. It therefore follows that a competence set is a collection of generic competences widely distributed across the three institutional spheres and hence highlights that competences can be consciously 
reconfigured, redirected, transformed and appropriately shaped, and integrated into existing competences as well as external resources (cf. Teece et al. 1997). Conversely, missing and/or poor competences may freeze interactive innovation processes and lock them in the past.

A sole focus on actors and the relationships between them, typical of innovation system studies, may even blur the view on how systems actually function and what drives them; hence, it is important to make a distinction between organisations and competences. By approaching actors indirectly through competences, it might be possible to clarify and specify the roles that they play in translating new knowledge into viable products and services. For these reasons, the main rationale in constructing a competence set model is (a) to specify what kind of competences are called for in a Triple Helix constellation and (b) to identify the competences that keep a Triple Helix constellation continuously adapting to changing economic landscapes. The competence set may thus also be used (c) to serve as a tool in a search for systemic failures as well as shared interests, problems, opportunities and capabilities, as suggested in the management literature (Pralahad and Hamel 1990). Consequently, a competence set model is an analytical tool geared towards identifying how different competences of many actors could be integrated with one another both horizontally and vertically in such a way that a constructed set would serve both the entire system and actors embedded into it. The assumption here is that generic competences need to be identified and analysed empirically case by case but a thematic framework is needed to guide the search.

The thematic framework was constructed by identifying studies focusing on innovation system functions, as generic competences are by necessity linked to the most important functions of any innovation system (see Lundvall et al. 2002; Lundvall and Lorenz 2006). In the literature on innovation system functions, knowledge development and diffusion is, quite self-evidently, acknowledged as a key function (Edquist 2005; Hekkert et al 2007; Hekkert and Negro 2009; Bergek et al 2008; Liu and White 2001). For his part, Eliasson (2000) does not discuss knowledge development as such, as his theory is dealing more with selection of winning technologies instead of sources of innovation. Most of the key authors include market formation, framing and creation of strategic awareness of new technologies and mobilisation in their discussion of the key innovation system functions (Edquist 2005; Hekkert et al 2007; Hekkert and Negro 2009; Bergek et al 2008; Jacobsson and Bergek 2004; Rickne 2000). Eliasson (2000), Hekkert and Negro (2009) and Bergek et al (2008) also incorporate in the set of system functions entrepreneurial activity. Edquist (2005), Hekkert and Negro (2009), Bergek et al (2008) and Rickne (2000) remind about the importance of legitimization, and Eliasson and Eliasson (1996) pay extensive attention to venture finances. In line with Liu and White (2001), Eliasson and Eliasson (1996) add detection of end-values in the debate while Edquist (2005), Hekkert and Negro (2009), Bergek et al 2008, Liu and White (2001) and Rickne (2000) emphasise the importance of interaction by highlighting networking, exchange of knowledge and bringing together complementary knowledge.

Following the close reading of the literature on innovation system functions, the competence set model was constructed to cover seven themes for the empirical work on the generic competences. Framing, mobilisation and networking were left out from the framework, as, instead of being system functions, they were identified as generic 
capabilities cutting through all the functions, and as such, they are embedded in the core competence thinking as well as the Triple Helix model (see e.g. Russel et al. 2015). Instead, drawing upon Eliasson (2000) and Liu and White (2001), industrial production or systematic production was included in the analysis, as it appears as important in the institutionalisation of innovations. The seven themes are the following: (1) knowledge creation and diffusion, (2) entrepreneurship, (3) finances, (4) legitimisation, (5) market formation, (6) systematic production and (7) identifying potential end-values. It is important to keep in mind that the seven functions, labelled here as themes, are not generic competences as such but they are used in the identification of them. Quite naturally, each of the themes includes a variety of specific capabilities that construct a generic competence. In a system-level analysis, the interaction of identified competences provides further empirical analysis with a point of departure in identifying the specific capabilities in a context of a specific transformation process of a specific Triple Helix constellation.

\section{Methodology and case}

This paper follows a single case study design to illustrate and highlight how the constructed competence set may play out with a case. The study covers the theoretical middle range in that it aims to understand the emergence of a new industry in its unique context and construct a conceptual model for adding analytical leverage to the Triple Helix model.

The emerging regenerative medicine concentration in Tampere and the prospective Finnish human spare parts industry serves as an example of emerging industry (see Sotarauta and Mustikkamäki 2015). It does not yet have a direct antecedent in the economy and thus entails the need to construct new competences and/or transform existing ones to support the birth and enlargement of an embryonic industry. The empirical study began in 2014 with the analysis of secondary data, including relevant journals, related newspaper articles, annual reports and respective policy documents. This phase identified the state of the art of the human spare parts industry both locally and globally. Next, 24 people, involved in different capacities in the development of regenerative medicine in Tampere, Finland, were interviewed in 2014 and early 2015. Fifteen of the interviewees were employees of BioMediTech (a joint institute of the University of Tampere and the Tampere University of Technology), and the rest of the interviewees were from local and regional development agencies, Tampere University Hospital, Ministry of Employment and the Economy, the Finnish Funding Agency for Innovation (TEKES) and a local firm. The interview themes were drawn from the competence set model and, in practice, comprised the seven generic competences (see Fig. 1). The main aim was to construct an understanding of what system-level generic competences are needed to enhance the emergence of science-based human spare parts industry and describe the current situation in Tampere. Competences and capacities related to actual scientific work, knowledge production, are not elaborated, but their importance is, of course, acknowledged, as they form the core in the emergence of any science-based industry.

The term regenerative medicine was forged in 2000 and is now widely used to describe biomedical approaches to healing the body by the stimulation of endogenous cells to repair damaged tissues or the transplantation of cells or engineered tissues to 


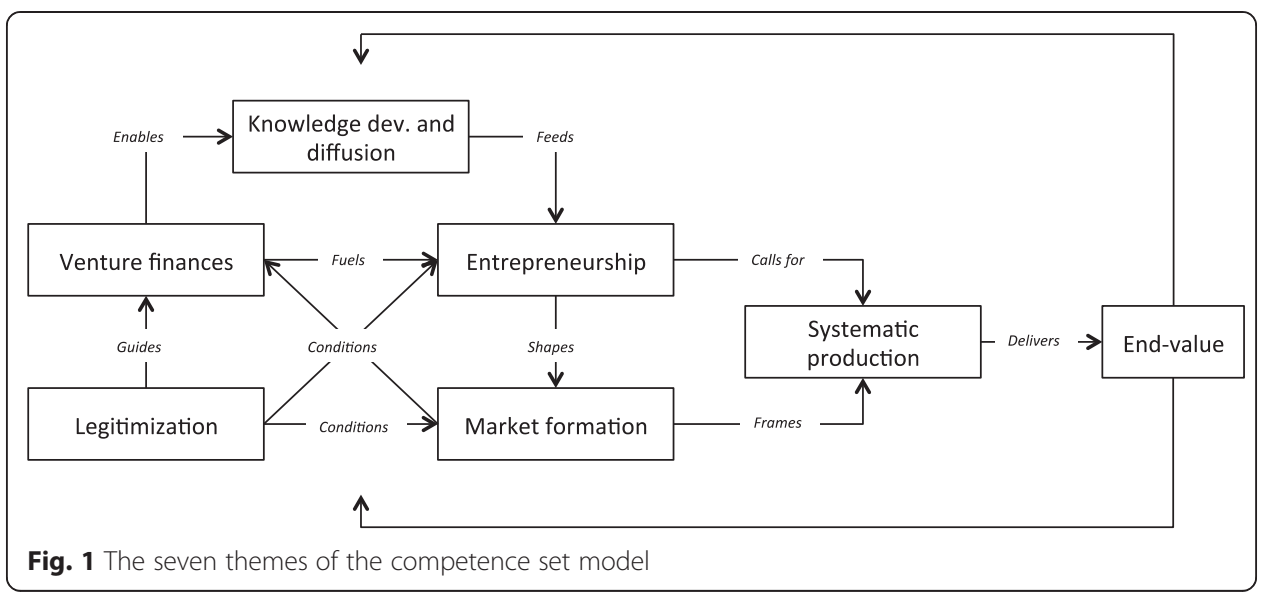

replace diseased or injured tissues (Riazi et al. 2009). The basic unit in regenerative medicine is a stem cell. Stem cells are biological cells found in all multicellular organisms. The potential of stem cells in clinical treatments is based on their multipotent ability. Stem cells are able to regenerate tissues and organs and act as building blocks for all tissues in the body (National Institutes of Health 2009). Regenerative medicine (RM) forms the third discipline in human healthcare alongside medicine and surgery (Polak et al. 2010), and, from a business point of view, cell therapy is defined as a fourth pillar in the healthcare industry alongside pharmaceuticals, biopharmaceuticals and medical devices (Mason and Manzotti 2009). Regenerative medicine has grown rapidly, and scientific achievements have created hopes for new treatments for severe incurable diseases, such as diabetes, Parkinson's disease, cancer and heart diseases. The promise of regenerative medicine is very exciting, but simultaneously, the cost of product development, and most notably clinical trials, for high-end applications is very high (Mason and Dunnil 2008a, 351).

In Tampere, the scientific research on regenerative medicine is based on close collaboration between the University of Tampere and the Tampere University of Technology, and the first discoveries were based on collaboration between biomaterial engineers, clinicians, cell biologists, technical experts and animal model experts (Sotarauta and Mustikkamäki 2015). The two universities institutionalised their collaboration in 2013 by establishing a joint research institute, Institute of Biosciences and Medical Technology (BioMediTech), that is a home base for approximately 250 scientists from the two universities. The unique nature of science and technology created at BioMediTech can be illustrated by the fact that in 2008, for the first time in the world, a patient's upper jaw was replaced with a bone transplant cultivated from the stem cells isolated from the patient's own fatty tissue (Sotarauta and Mustikkamäki 2015). The patient had lost roughly half of his upper jaw because of cancer and traditional medicine was unable to offer remedial treatment. In the process, the scientists were able to produce new bone cells by combining stem cells and biomaterials and then grow them into a jawbone of the correct shape and size (with the aid of a titanium frame) inside the patient's stomach muscle (Bionext 2010; Sotarauta and Mustikkamäki 2015).

In 2014, the international evaluation panel that carried out an extensive evaluation of the research activities at the University of Tampere concluded that 'research conducted at BioMediTech has an excellent standing nationally and internationally and the 
number of research projects and output from these projects is commensurate with the size of the Institute'. The evaluation panel also concluded that the projects are innovative and have clear translational potential in each thematic area of research (Hakala and Roihuvuo 2014). For its part, the international evaluation panel also asked how it would be possible to move discoveries from the laboratory or classroom to the clinic and ultimately turn these into products, policies or public information that impacts society' (Hakala and Roihuvuo 2014).

\section{The human spare parts industry discussed through a competence set Systematic production}

Systematic production refers to all those processes and methods that are used to transform science-based discoveries into permanent elements of a healthcare system. In regenerative medicine, the pressure to detect commercially viable products and services is increasing steadily but the issue of how to move from research and development to systematic production has not been fully answered yet (Mason and Manzotti 2009). One of the ways to translate the potential embedded in the scientific research into the market is via firms. However, the progress in regenerative medicine, especially in stem cell-based products, has been fairly modest, as it is fairly commonly seen that there ought to be clear evidence from phase II clinical trials before even pursuing the commercialisation phase (Parson 2008). The other option is to diffuse potential regenerative medicine services into medical practice through hospitals.

The prospective human spare parts industry is deeply embedded in scientific research, and those firms that would be interested in operating in the field need to have access to cutting edge research (Prescott 2011). Conversely, universities are expected to nurture innovations further into clinical trials before aiming at commercialisation in contrast to what is usually the case in medical innovation or what is normally expected before establishing a start-up and obtaining venture finance for it. In the field of regenerative medicine, firms need to have access to cutting edge research, as the scientists introduce new ideas and have the personal level networks needed for generating funding and establishing a start-up (Murray 2004; Prescott 2011). Therefore, the role of scientists becomes more prominent than is the case in many other fields of medicine as the markets are underdeveloped and as the demand is only beginning to emerge. Consequently, in a new science-based field like regenerative medicine, the scientific community needs to be competent not only in science but also in shaping the technology market, as they may be the only actors who can understand the potential embedded in the science and technology in question. This again calls for novel competences, and for these purposes, governments, e.g. in the USA and UK, are establishing regenerative medicine translation centres and funding clinical trials in cell therapy (Mason et al. 2011).

Our interviews clearly revealed that the questions related to systematic production, either commercially or non-commercially, have been on the agenda in Tampere since the early days of regenerative medicine-related research (early 2000s) (Sotarauta and Mustikkamäki 2015). Interviewees revealed how the idea of establishing a 'Hospital for Advanced Therapies' for treating patients suffering from facial bone deficiencies, and thus exploiting revolutionary new technology, moved to preparatory phase but did never materialise. Additionally, a special planning group designed a business plan for a 
university-based venture, but it was not executed either. As a member of the management team put it: 'The world [referring to the universities in question and global markets] was not ready for those ideas yet, nor were we'. Indeed, the core actors have not found solutions for moving forward beyond clinical experimentations, except licencing technology to an external party, and it is obvious that the generic competences, in the system broadly speaking, were not as developed as those in actual science.

The university hospital either has not made any major efforts to establish regenerative medicine in its standard repertoire, and it has not proactively constructed required competences. As a joint municipal authority of 22 municipalities, its mission is not to serve as an 'innovation platform for new technology' but to provide approximately one million Finns with a timely and equal access to specialised medical care. It, however, conducts clinical research and operates in close collaboration with the university. The university hospital is not likely to adopt a more strategic approach in the near future if there will not be significant pressure either from the society at large (in practice the public healthcare policy) or abundant number of individual medical doctors. In the future, the hospital's attitude towards regenerative medicine may be crucial; it is not only becoming legitimised part of the Finnish healthcare systems but also in moving towards large-scale systematic production.

In addition, the University of Tampere, the institutional home of regenerative medicine, is the most social science-oriented university in Finland, and hence, its experience in technology transfer and commercialisation is weak and related competences have been almost non-existent. For its part, BioMediTech has pushed the university to develop its competences on these fronts. To construct the commercialisation competences, BioMediTech has utilised the so-called Tutli funding that is a funding programme of TEKES. It is a specific government policy tool not only to support the commercialization of potential scientific discoveries but also to construct related competences within universities (Heinonen 2015).

\section{Market formation}

What makes the situation especially challenging is that regenerative medicine is a fairly new and quickly evolving form of science, and human spare parts industry is in an embryonic state. It is a well-known fact that radical innovations do not penetrate economies without emergence of a new market or significant changes in an existing one, and therefore, understanding the dynamics of market formation is seen here as one of the generic competences. Even though understanding of market formation is considered here as one of the generic competences in a competence set, its driving forces are more often than not considered as exogenously defined, and typically, it is seen to follow linear change patterns. Market formation is often described as proceeding from a nursing phase to a bridging phase to a mass market (Jacobsson and Bergek 2004), and each of these phases is associated with specific barriers and challenges (Dewald and Truffer 2011, 287). An elaborate understanding of market formation processes needs to take into account the coevolution of the technological, institutional, political and user-related aspects of innovation and related markets (Dewald and Truffer 2011, 286). Even though it is 
virtually impossible to influence the market formation from a single location, it is vitally important to construct competences to monitor and understand market formation dynamics for seizing the opportunities when they emerge. In locations like Silicon Valley, with abundant influential actors from different areas of the market, it is possible to witness markets evolving, but in more peripheral locations like Tampere, there is a need for active competence building for entering emerging markets. In Tampere, it is well understood that there is a need to reach international markets and funding sources, as the country is small and opportunities thus limited. It is also understood that there is a need to strengthen the collaboration with the Finnish hospitals to gain first-user references close to home and make sure that the benefits of the science in question are available in the country that has funded the research.

In BioMediTech Tampere, strategic awareness about emerging markets is fairly good at a general level but shared generic competences to exploit emerging opportunities are not well developed. Additionally, the core actors in Tampere are not familiar with the international markets, specific to those products and services BioMediTech is specialising in, and there is no systematic monitoring of them either. BioMediTech has received public funding from national and local sources to strengthen its capacity to operate in the global markets but the specific competences to monitor and assess the emergent human spare parts industry are not systematically developed, and the interviews indicate that their relevance as a part of the system are not fully understood. BioMediTech Tampere has been fairly inward looking and has not aimed at tapping into expertise of public and/or semi-public development agencies that has been established to be of support to these kinds of commercialisation efforts. Instead, there are signs of widening gap between BioMediTech, development agencies and also firms. This is due to many national factors (see below), the most important local issue being that the earlier fairly wellestablished sharing of joint and individual competences (see Sotarauta and Mustikkamäki 2015) has been fading away as the universities have been struggling with the many internal issues related to founding a joint institute between two individual universities. However, BioMediTech and local and regional development agencies are slowly awakening to realise the consequences of unbalanced local system, and new competences are being built but they are still in their early phases of development.

At all events, the human spare parts industry has only begun to emerge; the market formation has barely begun. It is an emerging industry without an established position yet. According to Alliance for Regenerative Medicine (ARM 2014), there are approximately 700 companies globally in the field of regenerative medicine (out of which 247 companies are dedicated to cell therapies). ARM divides the emerging market to four sub-groups: therapeutics and devices (56\%), tools (19\%), tissue banks (13\%) and services (12\%). According to Grand View Research (2013), in 2013, the estimated size of the regenerative medicine market size was $\$ 30.16$ billion from which the stem cell technology market was $\$ 12.8$ billion. Depending on what industries are included in regenerative medicine, market size estimations vary greatly but as the clinical trials proceed, also, the science push increases. 


\section{Entrepreneurship and venture finances}

As entrepreneurs take advantage of new business opportunities generated by new knowledge, and as they turn the potential of new knowledge, networks and markets into new business opportunities (Hekkert et al. 2007), their generic competences related to market understanding are of importance in moving towards commercialisation and potentially also making regenerative medicine an elemental part of the healthcare system. Additionally, entrepreneurs possess generic competences that enhance generation of diversity and diffusion of new knowledge (Drucker 2014; see for university-run enterprises, Zhou 2014). Entrepreneurial activity is usually considered one of the core activities in selecting viable alternatives from emerging ideas and knowledge (Hekkert et al. 2007). Quite naturally, in contrast to a scientist, whose main motivation is to create new knowledge and thus also novel opportunities, the entrepreneur's motivation revolves around the practical actualisation of these (Drucker 2014).

In BioMediTech, as explained in the previous sections, the competences related to science and technologies have developed favourably but business formation has yet to emerge. There have been over 10 spin-off firms as well as around 100 patents from BioMediTech and its predecessors, but the firms have not grown substantially. In Tampere, there are several biomaterial firms but, at least so far, no such entrepreneurs have surfaced, which would exploit the science and technology created in BioMediTech. Furthermore, there are no discussions between existing firms in Finland and BioMediTech or strategic efforts to create a nourishing local ecosystem for start-ups to emerge and grow. The current commercialisation strategy of BioMediTech focuses more on detecting major international dedicated actors to collaborate with than aiming at creating a local start-up ecosystem. All in all, our interviews clearly indicated that the general atmosphere towards the idea of having start-ups linked to BioMediTech is favourable, and there are several projects aimed at developing proofs of concept and raising funds for the next stages, but, as the competences related to boosting start-up community are still poorly developed, the international incumbents are seen as a favourable route forward. At BioMediTech, several explicit support measures to strengthen the entrepreneurial competences have been launched. These include recruiting additional staff with complementing capabilities in issues related to commercialisation, patenting and licencing; training scientists for commercialisation and seeking help to construct local competences from the USA and Belgium. Indeed, our interviews indicated clearly that these have been necessary but not sufficient measures if other competences in the system do not develop favourably. The efforts are more based on strengthening competences in a single organisation, instead that of an entire system, and therefore, the measures do not meet the scope of challenges.

Public funding has been extensively received to support the emergence of regenerative medicine but private venture finance has not found its way to Tampere, and hence, there is a need to find a proper balance between finding dedicated incumbents to collaborate with and supporting establishment of venture finance-backed start-ups to showcase the local scientific potential and, of course, to grow by themselves if possible. A well-functioning Triple Helix constellation requires competent venture financiers who recognise and finance the entrepreneurs, and hence, for their part, play an important role in the selection process. As previously shown, the catalytic role of venture financiers is often crucial in the emergence of new industries (Florida and Kenney 1988; 
von Burg and Kenney 2009). The challenge for new ventures is to 'carve out a new market, raise capital from sceptical sources, recruit untrained employees, and cope with other difficulties stemming from their nascent status' (Aldrich and Fiol 1994, 645). Moreover, as Pisano (2006) argues, biotechnology is a challenging sector for three reasons: (a) the uncertainty of the outcomes of the science and technology, (b) the heterogeneous and complex nature of the science, and (c) the need for long cumulative learning. All this calls for patient and future-oriented funding. These observations describe the situation BioMediTech is facing very well.

Additionally, the difficulty is that there are no Finnish venture capitalists that would invest in regenerative medicine, and as a whole, Finnish venture capital is a scarce resource (Sorvisto and Sotarauta 2016). The competences to fund the commercialization of regenerative medicine are poorly established in Finland. For these reasons, to raise venture capital BioMediTech needs to seek it from abroad but the abilities to sell the idea to a foreign venture capitalist have yet to emerge, and there are no real connections to potential venture capital sources, i.e. 'independently managed dedicated pools of capital that focus on equity or equity-linked investments in privately held, high growth companies' (Gompers and Lerner 1999, 349).

The emerging human spare parts industry in Tampere is not alone in its lack of entrepreneurial activity and difficulties in acquiring funding for commercialisation (see Hellman et al. 2011; Johnson et al 2011; Martin et al 2006), as it is the anatomy of the industry in itself (Pisano 2006). All this may be due to the fact that, in spite of huge promises, the market for the human spare parts industry has yet to emerge, and therefore, the competent companies and entrepreneurs have not seen the business opportunity yet in a broad sense. As suggested, a standard venture capital model is not working in cases where a large amount of money (e.g. \$100 million) and time (e.g. at least 10 years) are needed to finalise a product (Reynolds et al. 2013). In regenerative medicine, technological risk and burn rates are high, and a combination of high risk and long time-span is not a lucrative opportunity for a financier. For these reasons, according to Mason (2007), since the early enthusiasm of the 1990s, the funding in regenerative medicine has switched from venture capital and pharmaceutical firms to public finance, philanthropists and military sources. Regenerative medicine is a fairly typical case of an emerging science-based field that draws heavily on public funding, and private venture financiers become interested in the potential of its innovations only in the later phases of clinical trials (Parson 2008).

Mason (2007) states that three factors make it possible for a new venture to succeed: expert business management, simple but superior products and scalability of manufacture (Parson 2008). Consequently, for a venture capitalist to be convinced about a market potential of a novel product or service: (a) medical needs must be clearly identified, (b) savvy management team needs to be in place and (c) intellectual property needs to be protected (Parson 2008). Prescott (2011) also highlights the importance of third party endorsement for the product and an effective sales and marketing strategy. In Tampere, there are not savvy management teams attached to the local system that would possess the competences needed in moving forward, and neither there are products nor services packaged for international markets. In consequence, the generic competences needed in exploiting the opportunities in the emergence of new industry are still to be constructed. 


\section{Legitimisation}

Simultaneously, with the high hopes embedded in regenerative medicine, the emerging human spare parts industry faces both complex ethical and legislative issues and difficulties typical to new emerging industry, and hence, its emergence cannot be fully grasped without full appreciation of the issues related to legitimisation.

As innovation needs to become part of an incumbent regime, a new emerging industry needs to establish itself as a part of several systems (Hekkert and Negro 2009; Aldrich and Fiol 1994). To accomplish this, various actors need to innovate against the logic of those systems that are supposed to support them, and thus, generic competences related to legitimisation may be of utmost importance. It is worth reminding that the question is not about legitimating human spare parts industry in one specific system but several systems and hence broadly in the society. In the case under scrutiny, these are not only healthcare, science and innovation systems but also local/regional economic development systems.

Lack of legitimacy may be among the main obstacles for new ventures operating in emerging industries and/or markets, as new products, services and processes need to overthrow the existing regime. That, of course, frequently causes uncertainty and social anxiety. Consequently, reduction of social uncertainty and dealing with resistance to change are among the generic competences needed in an innovation system. These are here combined under the concept of legitimisation. Legitimisation refers to the sociopolitical process of legitimacy formation through actions by various organisations and individuals. Central features are the formation of expectations and visions as well as regulative alignment, including issues such as market regulations, tax policies and directions of science and innovation policy (Bergek et al. 2008). Legitimisation is about acquiring social acceptance of innovation, and it is a process that makes an innovation conform to the prevailing institutions (norms, values, habits and regulations) and/or to a process that targets the change of institutions for something new to emerge (Bergek et al 2008). Legitimisation is one of the most central selection mechanisms in any Triple Helix setting.

Earning legitimacy is a demanding process, as a society is unfamiliar with the industry and new innovations related to it. The human spare parts industry is not well defined yet, and there are only few or no standards and/or products and services against which society can judge the industry as appropriate. Of course, conversely, ambiguous or non-existing standards and services also present a great opportunity for a new venture in an emerging industry, as they may take a lead in defining the industry, determining the standards for it and establishing a dominant design for an entire field, and thus create legitimacy for the industry. In practice, it is rare that one single actor might be in a position to push for legitimacy alone, and more often than not it calls for actions from public, private and academic actors. There are multiple ways to legitimate a new industry. At the organisational level, ventures must build trust with customers, firms in related industries and industry members. They also need to develop a knowledge base by clearly defining issues (e.g. the level of abstraction, use of existing knowledge, internal consistency) (Aldrich and Fiol 1994),

Mason and Dunnil (2008b) point out the importance of widely accepted technical standards because the lack of early agreement on standards might be damaging to the human spare parts industry. Currently, in developed countries, it is, of course, almost 
impossible to bring new therapies or medical devices into clinical use without any regulatory approval. Regulatory bodies, though, are not always up to date about biomedical scientific understanding and possibilities of technology, and thus, there are examples of evolutionary trajectories where regulation co-evolves with the innovation process and the market (Metcalfe et al. 2005). Statutes concerning clinical medical research in general cover much of the stem cell-based research, and only a few countries have adopted legislation devoted to stem cell research per se. In Finland, the ethical atmosphere and legislation have mostly been permissive (Stem cell research in the Nordic countries 2007).

In Tampere, realised experimental treatments have been regulated under Hospital Exemption for Advanced Therapy Medicinal Products (ATMP). Even after several successful experimental treatments, and established expertise to cultivate bone tissue from stem cells, regulators do not fully know what the regulatory details are for these kinds of new products and treatments in Finland. There actually is an on-going dialogue between the regulators and representatives of BioMediTech to find out what is actually required and how to carry it out, and thus, the Tampere case confirms the earlier observations that regulation co-evolves with the innovation process and the market in the emerging industries (Metcalfe et al. 2005). In Finland, regenerative medicine is well legitimised in the science system including science and innovation funding but it is not as well legitimised in the healthcare system, as the treatments are mainly case-by-case experiments rather than established parts of the standard repertoire of the hospitals and the entire system. According to our interviews, in the hospital, the individual medical doctors comprise the core in the efforts to exploit the discoveries of regenerative medicine, and thus to legitimise it in their own specialisation areas, and so far, there has only been few champions for these efforts. Therefore, the limitation of a physician's responsibility regarding harm done to a patient during a treatment may have a major impact on clinical practice as well as new product and service development. If physicians alone carry the responsibility, the will to take risks at individual level is small compared to a situation where the government, hospital or a system as a whole carries part of the liability. In Finland, physicians are fairly well positioned to experiment with new technologies as the responsibility is shared in the system.

\section{End-values}

Liu and White (2001) suggest that, in the spirit of demand-led innovation, end-usegenerated innovation needs to be better acknowledged than earlier recommended in the innovation system literature. However, in the early stages of regenerative medicinerelated products and services, it is fairly hard to see user- or demand-led innovation emerging. The entire field is pushed forward by new developments in science, and the 'customer imagination' is not developed enough to demand new kinds of services. However, as the field is characterised by high hopes and global hype, there are a variety of expectations. Public policymakers and funding bodies are looking forward to increased employment and globally leading positions in a new trending field; our interviews revealed that this is the case in Tampere too. Scientists, for their part, aim to push the scientific frontier forward but also seek citations and fame. And of course, ultimately, there are incurable or difficult to cure diseases and thus plenty of patients who might benefit from scientific breakthroughs in regenerative medicine providing 
them with new hope. In all cases, potential and actual beneficiaries of innovations in regenerative medicine consist of heterogeneous sets of actors that all have their own hopes and fears. Expectations are not as clear as we might assume; any Triple Helix is a nexus of many expectations and desires, and hence, consensus spaces are of importance, but not easily constructed and maintained. Therefore, it is important to scrutinise what the potential end-results might be by focusing on not only the end-use of specific innovations, or demand-led innovation, but also the end-values various actors expect to get out of it. It is important to note that 'a firm,' 'product' or 'service' is not an endvalue, as is often seen, but the value generated for the society, economy and individuals at large.

In Tampere, there have been only limited discussions, not to mention public debates, on the end-values, and it may be that the lack of public debates are among the reasons why legitimisation processes are still uneven depending on the sub-system, and why market offerings have been slow to emerge, and why the Tampere University Hospital has not adopted a more strategic attitude towards it. In Tampere, there are no efforts to boost public discussion on the public and/or private end-values of the money invested in regenerative medicine either, and it seems clear that there is no widely shared awareness of the importance of public debates in the emergence of a new industry and thus no competences to set these in motion. Perhaps, the human spare parts industry has not begun to emerge in Finland, as it is globally underdeveloped, funding is scarce but also because there is no public debate concerning the end-values or potential risks involved in regenerative medicine and human spare parts industry.

The core actors have not understood the value of generating a public discussion on the future prospects of regenerative medicine and human spare parts industry more broadly. As the end-values are only vaguely debated outside the scientific and some policy circles, it also is difficult to begin a systematic construction of such competences that are needed in taking major steps forward. In addition, there are no 'innovation evangelists' who would work for increased awareness of the emerging industry and build a critical mass and competent management teams of support for it. An evangelist is a special role in the system with established competences in promoting the use of a particular technology through talks, bonding with gatekeepers, writing articles for professional as well as general media, blogging, boosting user demonstrations, presenting recorded demonstrations or the creation of sample projects (Beatty and Gordon 1991; Lucas-Conwell 2006). Innovation evangelists are playing an important role in the construction of collective beliefs that again are central in a design of new strategies (Sotarauta 2016) and construction of related competences.

\section{Conclusions}

This paper suggests that to truly understand the dynamics of the Triple Helix model and how new discoveries are commercialised and diffused into the society, there is a need to study also interacting generic competences that either enhance or hamper collaboration in Triple Helix constellations. Moreover, it is believed that construction of well-functioning innovation and knowledge spaces, and related consensus space, calls for novel ways to analyse and develop interrelated but differing competences from Triple Helix instead of organisational perspectives (see also Ranga and Etzkowitz 2013). For these purposes, a set of generic competences was introduced and discussed, and it 
was also shown how they play together, or not, in a specific case. The dominant generic competences are related to the generation of new knowledge and the selection of winning knowledge, products and/or services and retention of them in the economy, but, as was shown, several other generic competences are called for in the system to make a lasting impact on the society, to institutionalise the new discoveries. As the case study reported in this paper shows, it may be difficult to move beyond scientific excellence in an emerging field, in which not all the generic competences have developed yet to support each other. Any Triple Helix constellation is by definition a complex ensemble of actors, and as the Tampere case also reveals, in the course of events, it may be fairly difficult to see how the lack of competences related to making sense of emerging markets, debating potential end-values and legitimisation may end up hampering the functionality of consensus and innovation spaces, and thus also seemingly straightforward commercialization efforts.

The main obstacles in a case under scrutiny are related to insufficient funding, difficulties in the technology transfer processes, poor understanding of emerging markets and acquisition of capabilities needed in the form of competent management teams. Many of these issues are beyond what can be expected from universities only, and quite naturally, the emergence of the human spare parts industry is dependent on many competences of all three institutional spheres of the Triple Helix model. It might be possible to argue, for example, that the local university hospital, owned by the local government, ought to integrate new treatments into its standard repertoire, but, in practice, the mix of potential end-values are poorly identified and not properly debated, and thus, it is difficult for the hospital to take necessary measures or even understand what is at stake. And here, the competences of social scientists and/or local politicians might prove invaluable. Moreover, it would be easy to suggest that the universities ought to strengthen their competences related to entrepreneurship, market formation, technology transfer and commercialization, but as important, it is to ask where complementary competences could be found from and how they could be tapped into and integrated into the local Triple Helix constellation. So far, they have been found in the USA and Belgium. In addition, there is a medical technology-specialised local development agency that played a central role in the early phases of regenerative medicine (see Sotarauta and Mustikkamäki 2015), but as the role of intermediaries has been questioned in the Finnish innovation system, it has been disintegrating from more recent developments. Interestingly, from a national innovation system point of view, this may be a well-argued position but, from a competence set point of view, well established, much needed and valuable local competences have been side-tracked more or less unintentionally.

The conclusion, and proposition for future on studies on triple helices, is that a balanced competence set influences positively the functionality of Triple Helix constellations, and more specifically knowledge, consensus and innovation spaces in the core of them, and provides all three institutional spheres with a tool to customise their interaction. It is important to note that the generic competences and a competence set based on them may be universally needed but their manifestations vary across countries and regions; different actors may introduce different generic competences depending on the past path, the system and the expertise of individual actors. Thus, the concept of competence set provides a tool to discuss the roles of various actors in a Triple Helix, and the competences they bring into play, and especially to detect poorly developed or non-existing competences. 


\section{Additional file}

Additional file 1: Translation of the abstract into Arabic. (PDF 273 kb)

Received: 26 November 2015 Accepted: 14 July 2016

Published online: 25 July 2016

\section{References}

Aldrich HE, Fiol CM (1994) Fools rush in: the institutional context of industry creation. Acad Manage Rev 19(4):645-670 ARM (2014) Regen med and advanced therapies state of the art industry briefing. Alliance for regenerative medicine Beatty CA, Gordon JRM (1991) Preaching the gospel: the evangelists of new technology. Calif Manage Rev 33(3):73-94 Bergek A, Jacobsson S, Carlsson B, Lindmark S, Rickne A (2008) Analyzing the functional dynamics of technological innovation systems: a scheme of analysis. Res Policy 37(3):407-429

Bionext (2010) Innovation for well-being 2003-2010. Bionext, Tampere

Brown RB (1994) Refrain the competency debate management knowledge and generic competence in graduate education. Management 25(2):289-299

Cai Y (2014) Implementing the Triple Helix model in a non-Western context: an institutional logics perspective. Triple Helix 1:1

Cai Y, Cui $L$ (2015) The roles of universities in fostering knowledge-intensive clusters in Chinese regional innovation systems. Sci Public Policy 42(1):15-29

Dewald U, Truffer B (2011) Market formation in technological innovation systems—diffusion of photovoltaic applications in Germany. Ind Innov 18(3):285-300

Drucker PF (2014) Innovation and entrepreneurship. Routledge, Abingdon

Durand T (1998) The alchemy of competence. In: Hamel G, Pralahad C K, Thomas H, O'Neal D (eds) Strategic Flexibility: Managing in a Turbulent Environment. John Wiley \& Sons, Chichester, pp 303-330

Edquist C (2005) Systems of innovation: perspectives and challenges. In: Oxford Handbook of Innovation. Oxford University Press, New York, pp 181-208

Eliasson G (2000) Industrial policy, competence blocs and the role of science in economic development. J Evol Econ 10:217-241

Eliasson G, Eliasson A (1996) The biotechnological competence bloc. Rev Econ Ind 78:7-26

Etzkowitz H, Leydesdorff L (1997) Universities and the Global Knowledge Economy: A Triple Helix of University-IndustryGovernment Relations. London: Pinter.

Etzkowitz H (2008) The Triple Helix: University-Industry-Government Innovation In Action. London: Routledge.

Florida R, Kenney M (1988) Venture capital and high technology entrepreneurship. J Bus Ventur 3(4):301-319

Gompers PA, Lerner J (1999) The venture capital cycle. MIT Press, Cambridge MA

Grand View Research (2013) Global stem cells market. Available from: http://www.grandviewresearch.com/pressrelease/global-stem-cells-market. Accessed 18 Nov 2015

Hakala J, Roihuvuo (toim.) (2014) Research Assessment Exercise at the University of Tampere 2014 - Final Report (UtaRae2014). University of Tampere; Kopioniini Oy, Tampere.

Heinonen T (2015) Management of innovation in academia: a case study in Tampere. J Technol Manage Innov 10(2): $198-210$

Hekkert M, Negro S (2009) Functions of innovation systems as a framework to understand sustainable technological change: empirical evidence for earlier claims. Technol Forecast Soc Chang 76(4):584-594

Hekkert MP, Suurs RAA, Negro SO, Kuhlmann S, Smits REHM (2007) Functions of innovation systems: a new approach for analyzing technological change. Technol Forecast Soc Change 74:413-432

Hellman K, Johnson P, Bertram T, Tawil B (2011) Challenges in tissue engineering and regenerative medicine product commercialization: building and industry. Tissue Eng Part A 17(1/2):1-3

Jacobsson S, Bergek A (2004) Transforming the energy sector: the evolution of technological systems in renewable energy technology. Ind Corp Chang 13(5):815-849

Javidan M (1998) Core competence: what does it mean in practice. Long Range Plann 31(1):60-71

Johnson P, Bertram T, Tawil B, Hellman K (2011) Hurdles in tissue engineering/regenerative medicine product commercialization: a survey of North American academia and industry. Tissue Eng Part A 17(1/2):5-15

Lester R (2007) Universities, innovation and the competitiveness of local economies: an overview. In: Lester R, Sotarauta $M$ (eds) Innovation, universities and the competitiveness of regions. Technology review. Tekes, Helsinki, p 214

Liu X, White S (2001) Comparing innovation systems: a framework and application to China's transitional context. Res Policy 30(7):1091-1114

Lucas-Conwell F (2006) Technology evangelists: a leadership survey, paper presented in Prepared for the SDForum Conference on "Technology Leadership and Evangelism in the Participation Age". 4 December 2006.

Lundvall B, Lorenz E (2006) How Europe's economies learn: coordinating competing models. Oxford University Press, Oxford

Lundvall B- $\AA$, Johnson B, Andersen E, Dalum B (2002) National systems of production, innovation and competence building. Res Policy 31:213-231

Martin P, Coveney C, Kraft A, Brown N, Bath P (2006) Commercial development of stem cell technology: lessons from the past, strategies for the future. Regen Med 1(6):801-807

Mason C (2007) Editorial_regenerative medicine 2.0. Regen Med 2(1):11-18

Mason C, Dunnil P (2008a) A brief definition of regenerative medicine. Regener Med 3(1):1-5.

Mason C, Dunnil P (2008b) A brief definition of regenerative medicine. Regener Med 3(1):1-5

Mason C, Manzotti E (2009) Regen: the industry responsible for cell-based therapies. Regen Med 4(6):783-785

Mason C, Brindley D, Culme-Seymour E, Davie N (2011) Cell therapy industry: billion dollar global business with unlimited potential. Regen Med 6(3):265-272 
Metcalfe J S, James A, Mina A (2005) Emergent innovation systems and the delivery of clinical services: the case of intra-ocular lenses. Research Policy 34:1283-1304.

Murray F (2004) The role of academic inventors in entrepreneurial firms: sharing the laboratory life. Res Policy 33:643-659

National Institutes of Health (2009) Stem cell basics. Available from: http://stemcells.nih.gov/staticresources/info/basics/ SCprimer2009.pdf. Accessed 18 Nov 2015

Parson A (2008) Stem cell biotech: seeking a piece of the action. Cell 132:511-513

Pisano G (2006) Profiting from innovation and the intellectual property revolution. Res Policy 35(8):1122-1130

Polak J, Bravery C, Prescott C (2010) Translation and commercialization of regenerative medicine. J R Soc Interface 7: S675-S676

Pralahad C K, Hamel G (1990) The core competence of the corporation. Harvard Business Review, Boston MA, p 79-91

Prescott C (2011) The business of exploiting induced pluripotent stem cells. PhilosTrans R Soc B 366:2323-2328

Ranga M, Etzkowitz H (2013) Triple Helix systems: an analytical framework for innovation policy and practice in the knowledge society. Ind High Educ 27(3):237-262

Reynolds E, Samel H, Lawrence J (2013) Learning by building: Complementary assets and the migration of capabilities in U.S. innovation firms. Working paper series 13/001, Cambridge MA; MIT Industrial performance center.

Riazi AM, Kwon SY, Stanford WL (2009) Stem cell sources for regenerative medicine. Methods Mol Biol 48:55-90

Rickne A (2000) New technology-based firms and industrial dynamics - Evidence from the technological system of biomaterials in Sweden, Ohio and Massachusetts, Doctoral dissertation, Department of Industrial Dynamics, Chalmers University of Technology, Göteborg.

Russel M, Huhtamäki J, Still K, Rubens N, Basole R (2015) Relational capital for shared vision in innovation ecosystems. Triple Helix 2(8):1-36

Sorvisto P, Sotarauta M (2016) Venture capital ecosystem in Finland—fragile and thin. In: Sotarauta M, Heinonen T, Sorvisto P, Kolehmainen J (eds) Innovation ecosystems, competences and leadership human spare parts and venture finance ecosystems under scrutiny. Tekes Publication, Helsinki

Sotarauta M (2016) Leadership and the city: power, strategy and networks in the making of knowledge cities. Routledge, Abingdon

Sotarauta M, Mustikkamäki N (2015) Institutional entrepreneurship, power, and knowledge in innovation systems: institutionalization of regenerative medicine in Tampere, Finland. Environ Plan C 33(2):342-357

Sotarauta M, Linnamaa R, Suvinen N (2003) Tulkitseva kehittäminen ja luovat kaupungit: Verkostot ja johtajuus Tampereen kehittämisessä [Interpretative promotion of economic development and creative cities: Networks and leadership in the economic development policy of Tampere]. Tekniikan akateemisten liitto ja Tampereen yliopisto, Sente-julkaisuja, Tampere.

Stem cell research in the Nordic countries (2007) Science, ethics, public debate and law. Nordforsk Policy Briefs 2007-2. Norden, Oslo

Teece DJ, Pisano G, Shuen A (1997) Dynamic capabilities and strategic management. Strateg Manag J 18(7):509-533

Tuomi I (1999) Corporate knowledge: theory and practice of intelligent organizations. Metaxis, Helsinki

von Burg U, Kenney M (2009) Venture capital and the birth of the local area networking industry. Res Policy 29(9):1135-1155

Wadhwa S, Rao S (2000) Flexibility: an emerging generic competence for managing high technology. Int J Technol Manag 19(7-8):820-845

Zhou C (2014) Four dimensions to observe a Triple Helix: invention of 'cored model' and differentiation of institutional and functional spheres. Triple Helix 1(11):1-20

\section{Submit your manuscript to a SpringerOpen ${ }^{\circ}$ journal and benefit from:}

- Convenient online submission

Rigorous peer review

- Immediate publication on acceptance

- Open access: articles freely available online

- High visibility within the field

- Retaining the copyright to your article 